\title{
Liver biopsies for chronic hepatitis C: Should nonultrasound-guided biopsies be abandoned?
}

\author{
Jennifer A Flemming MD¹, David J Hurlbut MD², Ben Mussari MD³, Lawrence C Hookey MD FRCPC ${ }^{1,4}$
}

\author{
JA Flemming, DJ Hurlbut, B Mussari, LC Hookey. Liver \\ biopsies for chronic hepatitis C: Should nonultrasound-guided \\ biopsies be abandoned? Can J Gastroenterol 2009;23(6):425- \\ 430.
}

BACKGROUND/OBJECTIVE: Liver biopsy has been the gold standard for grading and staging chronic hepatitis $\mathrm{C}$ virus (HCV)mediated liver injury. Traditionally, this has been performed by trained practitioners using a nonimage-guided percutaneous technique at the bedside. Recent literature suggests an expanding role for radiologists in obtaining biopsies using an ultrasound (US)-guided technique. The present study was undertaken study to determine if the two techniques produced liver biopsy specimens of similar quality and hypothesized that at our institution, non-US-guided percutaneous liver biopsies for HCV would be of higher quality than US-guided specimens.

METHODS: Liver biopsies from 100 patients with chronic HCV infection (50 consecutive US-guided and 50 consecutive non-US-guided), were retrospectively identified using a hospital histopathology database. All original biopsy slides were coded and prospectively reanalyzed by a single hepatopathologist who was blinded to the technique used in obtaining the biopsy. Additionally, all liver biopsies for chronic HCV infection completed at the centre from 1998 to 2007 were identified and the technique used was recorded. Biopsy quality was determined primarily by the number of complete portal tracts (CPTs) identifiable in the slides. The total length of specimen and the degree of fragmentation were secondary outcome measures.

RESULTS: There was a slight difference observed between the US-guided and non-US-guided groups in mean age (46.3 years versus 42.5 years, repectively; $\mathrm{P}=0.018$ ) but no differences in sex, presence of cirrhosis, bilirubin, creatinine, international normalized ratio, and grade or stage of disease. Biopsies obtained using the US-guided technique produced higher quality specimens than the non-US-guided technique based on our primary outcome of number of CPTs in the biopsy (11.8 versus $7.4 ; \mathrm{P}<0.001)$. US-guided specimens also were longer (24.4 mm versus $19.7 \mathrm{~mm}$; $=0.001$ ), had less fragmentation $(\mathrm{P}=0.016)$, and a higher overall histopathological quality assessment $(\mathrm{P}=0.026)$ than the non-US-guided biopsies. However, there was no significant difference between the two groups in the ability to grade and stage the disease (96\% US-guided versus $90 \%$ in non-US-guided $(\mathrm{P}=0.20)$. Over a 10 -year period, 763 biopsies for chronic HCV infection were identified with an obvious trend toward the increased use of US-guided technique observed at 2\% in 1998 to $85 \%$ in 2007.

CONCLUSIONS: US-guided liver biopsies for chronic HCV are the most common method of obtaining specimens at the Kingston General Hospital, Kingston, Ontario, and are of higher quality than non-US-guided specimens. However, there is no significant difference in the two techniques in the ability to grade and stage chronic HCV.

Key Words: Biopsy, HCV, Liver

\author{
Biopsies hépatiques pour l'hépatite $\mathrm{C}$ \\ chronique : Faut-il abandonner les biopsies \\ non guidées par échographie?
}

CONTEXTE/OBJECTIF : La biopsie hépatique a été la norme pour la stadification et la gradation des lésions hépatiques causées par le virus de l'hépatite $\mathrm{C}$ chronique. De tous temps, ces biopsies ont été effectuées au chevet du malade par des médecins dûment formés, à l'aide d'une technique percutanée, sans recours à l'imagerie. Selon la littérature récente, les radiologues jouent un rôle croissant dans l'obtention des biopsies guidées par échographie. La présente étude visait à déterminer si les deux techniques permettent d'obtenir des spécimens de biopsies hépatiques de même qualité et a formulé l'hypothèse selon laquelle, dans notre établissement, les biopsies hépatiques percutanées non guidées par échographie, dans les cas d'hépatite $\mathrm{C}$ chronique, seraient de meilleure qualité que les spécimens obtenus sous échographie.

MÉTHODE : Les biopsies hépatiques de 100 patients atteints d'hépatite C chronique ( 50 biopsies consécutives guidées par échographie et 50 biopsies consécutives non guidées par échographie) ont été retracées de manière rétrospective à partir de la base de données histopathologiques de l'hôpital. Tous les clichés de biopsies originales ont été encodés et réanalysés de manière prospective par un seul et même hépatologue, à l'insu de la technique utilisée pour l'obtention de la biopsie. De plus, toutes les biopsies hépatiques pour hépatite $\mathrm{C}$ chronique réalisées dans cet hôpital entre 1998 et 2007 ont été retracées et la technique utilisée a été consignée. La qualité des biopsies a été déterminée principalement par le nombre d'espaces portes complets (EPC) identifiables sur les clichés. La longueur totale des spécimens et le degré de fragmentation ont servi de paramètres secondaires.

RÉSULTATS : On a noté une légère différence entre les deux groupes (selon que l'échographie avait ou non été utilisée) pour ce qui est de l'âge moyen (46,3 ans vs 42,5 ans, respectivement; $\mathrm{p}=0,018$ ), mais aucune différence pour ce qui est du sexe, de la présence de cirrhose, des taux de bilirubine et de créatinine, du ratio normalisé international, du grade et du stade de la maladie. Les biopsies obtenues sous échographie ont donné lieu à des spécimens de meilleure qualité que la technique non guidée par échographie, selon notre paramètre principal, c'est-à-dire le nombre d'EPC dans le spécimen de biopsie (11,8 vs 7,4; p < 0,001). Les spécimens obtenus sous échographie étaient également plus longs (24,4 mm vs 19,7 mm; $\mathrm{p}=0,001)$, présentaient un degré moindre de fragmentation $(\mathrm{p}=0,016)$ et une qualité histopathologique globalement meilleure $(\mathrm{p}=0,026)$, comparativement aux biopsies non guidées par échographie. Toutefois, on n'a noté aucune différence significative entre les deux groupes quant à la capacité d'évaluer le grade ou le stade de la maladie (96\% sous échographie vs $90 \%$ sans échographie; $\mathrm{p}=0,20$ ). Au cours d'une période de dix ans, 763 biopsies pour hépatite $C$ chronique ont été retracée et on a observé une tendance manifeste à utiliser davantage la technique guidée par échographie, soit 2 \% en 1998, contre 85 \% en 2007.

CONCLUSIONS : Pour l'hépatite $\mathrm{C}$ chronique, les biopsies hépatiques guidées par échographie constituent la méthode la plus courante d'obtention de spécimens à l'Hôpital Général de Kingston, à Kingston, en Ontario et elles sont de meilleure qualité que les spécimens obtenus sans échographie. On ne note cependant aucune différence significative entre les deux techniques pour ce qui est de la capacité d'établir le grade ou le stade de l'hépatite $\mathrm{C}$ chronique.

${ }^{1}$ Gastrointestinal Diseases Research Unit, ${ }^{2}$ Department of Pathology and Molecular Medicine, ${ }^{3}$ Department of Diagnostic Imaging,

Queen's University; ${ }^{4}$ Gastroenterology Division, Hotel Dieu Hospital, Kingston, Ontario.

Correspondence: Dr Lawrence C Hookey, Gastroenterology Division, Sydenham 4, Hotel Dieu Hospital, 166 Brock Street, Kingston, Ontario

K7L 5G2. Telephone 613-544-3400 ext 2288, fax 613 544-3114, e-mail hookeyl@hdh.kari.net

Received for publication January 25, 2009. Accepted March 29, 2009 
$\mathrm{L}$ iver biopsy is considered to be the gold standard for the investigation of many hepatic diseases including the grading and staging of chronic hepatitis $\mathrm{C}(\mathrm{HCV})$. Historically, this has been performed by trained gastroenterologists and hepatologists using a nonimage-guided percutaneous technique. A typical liver biopsy specimen represents $1 / 50,000$ of the total mass of the liver (1). Currently, the number of complete portal tracts (CPTs) is considered a primary determinant of biopsy adequacy for reliable grading and staging of chronic hepatitis (1-3). Recent studies investigating liver biopsy samples for HCV have suggested that specimens need to be at least $2 \mathrm{~cm}$ in length and contain between 11 and 15 CPTs for optimal diagnostic accuracy (4). The length of the biopsy and number of CPTs obtained have been found to be related to the type of needle used (Menghini versus Tru-Cut) and needle gauge (5).

In recent years, the widespread use of ultrasonography has enabled an expanded role for the radiologist to obtain ultrasound (US)-guided liver biopsies. A series from France in 2000 (6) documented that radiologists performed $56 \%$ of liver biopsies, and a recent study from Calgary, Alberta (7), demonstrated that $90 \%$ of percutaneous liver biopsies (PLBs) are performed by radiologists.

Although the rate of serious complications from the procedure is low (8), regardless of the technique used, studies have suggested that the US-guided technique decreases the amount of pain requiring treatment $(9,10)$ and hospitalization rates $(9)$, and is cost-effective based on hypothetical decision-making models $(11,12)$. Proponents have suggested that this is a result of the ultrasonic identification of important anatomy including blood vessels, bile ducts, colon and lung, and directing the operator away from these structures. However, there is no consensus as to whether US-guided biopsies should be considered the standard of care (13).

There have been no randomized trials that compared the quality of PLB for chronic HCV obtained from US-guided versus non-US-guided liver biopsy techniques. A prospective study from Ireland (10) that addressed this question did not find any difference in the diagnostic yield of the specimens (98\% guided versus 94\% nonguided; $\mathrm{P}=0.15$ ). However, it did show significantly more CPTs in the non-US-guided versus US-guided group $(7.8$ versus $6.3 ; \mathrm{P}<0.0001)$. In a systematic review (5), a total of 5392 specimens from US-guided biopsies and 1369 specimens from non-US-guided biopsies were anaylzed. It showed that specimens obtained from US-guided biopsies were longer $(20.5 \mathrm{~mm}$ versus $14.4 \mathrm{~mm} ; \mathrm{P}=0.021)$ but there was no significant difference in the number of CPTs compared with the non-US-guided technique ( 8.3 versus $5.3 ; \mathrm{P}=0.13$ ). A preliminary report (14) has shown that the specimens obtained from non-US-guided PLBs were longer, wider and contained more CPTs than US-guided and transjugular liver biopsies.

There is no clear consensus on which technique provides better quality liver biopsy specimens (13). However, there appears to be a trend among hepatologists toward using the US-guided technique in North America $(7,15)$.

The present study was undertaken to determine how PLBs were being performed at The Kingston General Hospital $(\mathrm{KGH})$, Queen's University, Kingston, Ontario and to determine if the quality of the biopsy specimen is affected by the technique used to obtain the tissue.

\section{METHODS}

\section{Specimen identification}

PLBs from 100 patients with chronic HCV were obtained from 50 consecutive US-guided and 50 consecutive non-US-guided procedures, performed to evaluate disease grade and stage. These specimens were retrospectively identified from November 2003 to December 2005 using the histopathology database at $\mathrm{KGH}$, Kingston, Ontario. This database is composed of both electronic and paper records that document all pathological specimens obtained at $\mathrm{KGH}$. The specimens were initially identified electronically using the keyword "liver". The list of specimens generated was then crossreferenced with the paper records to ensure an inclusive consecutive list. HCV infection was confirmed by either positive viral serology or clinical notes indicating that the patient was known to have chronic HCV. Biopsies obtained intraoperatively through a transjugular approach, or for indications other than to grade and stage chronic HCV, were excluded. One patient provided two biopsy specimens.

\section{US-guided biopsies}

US-guided biopsies were performed in the interventional radiology suite at $\mathrm{KGH}$ by one of three interventional radiologists or senior radiology residents. All patients received intravenous fentanyl and midazolam for procedural sedation and local anesthesia with $1 \%$ lidocaine was used. The left lobe of the liver was preferentially identified under US guidance if technically feasible. Two core liver tissue samples were obtained using an 18-gauge ASAP needle (Boston Scientific, USA). The patients were observed in the radiology department for $4 \mathrm{~h}$ after biopsy and were then discharged home if stable.

\section{Non-US-guided biopsies}

Non-US-guided biopsies were performed in the outpatient procedures unit of the Hotel Dieu Hospital (Kingston, Ontario) by staff gastroenterologists or gastroenterology fellows. These specimens were all referred to $\mathrm{KGH}$ for interpretation. The upper and lower borders of the liver were identified by percussion of the right anterior axillary line at end expiration. Local anesthetic ( $1 \%$ xylocaine) was then infiltrated and the specimen was obtained using a 16-gauge Jamshidi needle (Cardinal Health, Canada). One core liver tissue sample was obtained unless the sample appeared inadequate to the operator either by size or fragmentation, at which time an additional core was acquired. All patients were observed in the outpatient procedures unit for several hours after the procedure and discharged home in stable condition.

\section{Specimen analysis}

Once identified, each biopsy was coded using a random number generator to determine the order in which the slides would be presented to the pathologist. A single hepatopathologist $(\mathrm{DH})$, who was blinded to the technique, prospectively reviewed each biopsy. Each specimen was scored according to a histopathological evaluation form modified from Farrell et al (10) (Figure 1). Evaluation included the number of CPTs, the number of partial portal tracts (PPTs), the estimated area of the biopsy specimen, the number of central veins, the aggregrate length of the biopsy specimen ( $\mathrm{mm}$ ), the maximum biopsy core width $(\mathrm{mm})$, the presence of fragmentation, the grade and stage of disease based on the method of Batts and Ludwig (16), and the presence of extrahepatic tissue. 


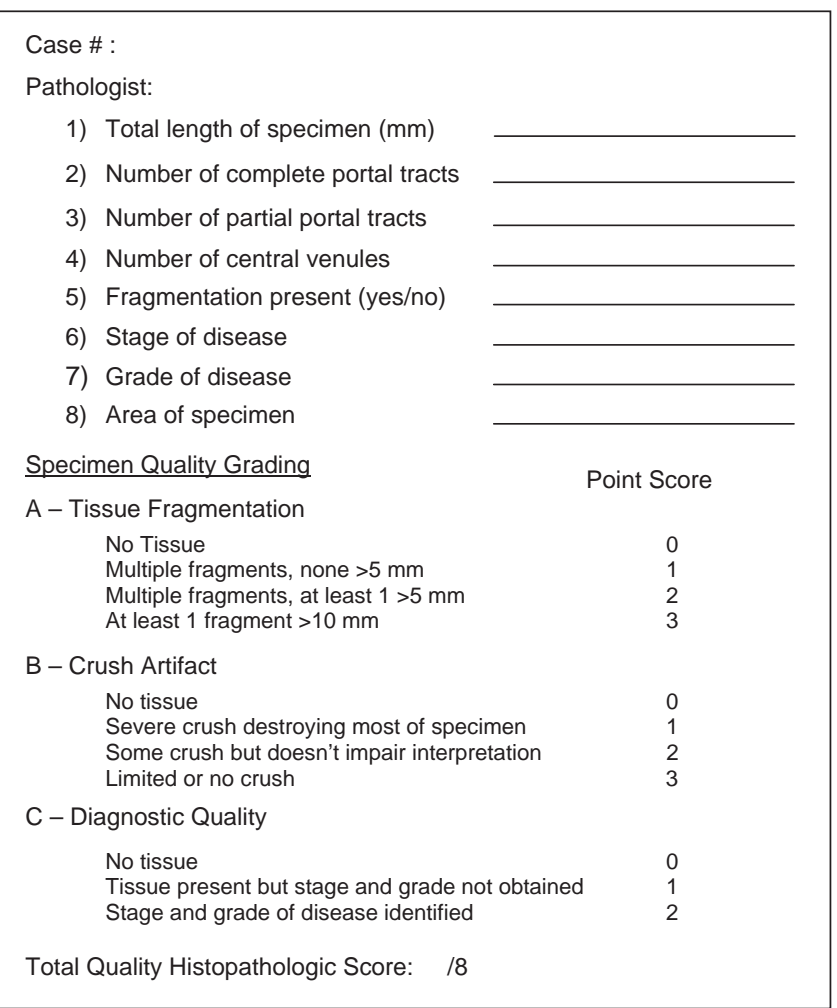

Figure 1) Liver biopsy specimen evaluation form

In addition to objective measures to assess specimen quality, subjective quality was measured using a total quality histopathological score (Figure 1). This score is comprised of the degree of fragmentation, amount of crush artifact and the ability of the hepatpathologist to confidently grade and stage the chronic HCV from the biopsy specimen.

$\mathrm{CPTs}$ were defined as connective tissue foci within the liver parenchyma with a complete circumference and containing at least two luminal portal structures. PPTs were defined as connective tissue foci within the liver parenchyma not meeting the criteria for CPTs. Length of the biopsy specimen was defined as the aggregate length of all fragments. Adequacy for tissue diagnosis was based on the ability of the pathologist to confidently grade and stage the chronic HCV.

As a further estimate of sample size, the biopsy area was measured directly from histological slides using the Micro Computing Image Device (MCID Elite version 6) image analysis system (Imaging Research Inc, Canada). Briefly, low magnification microscopic images of each liver biopsy were individually digitized. Area measurements were then calculated from digitized images using the system software after calibration using a $1 \mathrm{~mm}$ (100 $\mu \mathrm{m}$ divisions) calibration reticle to give area output data in $\mathrm{mm}^{2}$. Digitized images with the system generated area overlays, and area measurements were then archived.

Demographic data were gathered from review of both electronic and paper charts at $\mathrm{KGH}$, and included age, sex, HCV genotype, presence of cirrhosis, type of biopsy needle used, number of passes of biopsy needle and postprocedure complications.
TABLE 1

Patient demographics

\begin{tabular}{lccc}
\hline & \multicolumn{3}{c}{ Biopsy } \\
\cline { 2 - 3 } Demographic & $\begin{array}{c}\text { Ultrasound- } \\
\text { guided (n=50) }\end{array}$ & $\begin{array}{c}\text { Nonultrasound- } \\
\text { guided (n=50) }\end{array}$ & P \\
\hline Age, years (mean \pm SD) & $46.3 \pm 7.7$ & $42.5 \pm 8.3$ & 0.018 \\
Sex (female/male) & $12 / 38$ & $15 / 35$ & 0.499 \\
Cirrhosis present, n & 3 & 7 & 0.182 \\
Bilirubin, $\mu$ mol/L (mean \pm SD) & $12 \pm 7.0$ & $10.3 \pm 5.9$ & 0.257 \\
Creatinine, $\mu$ mol/L (mean \pm SD) & $78.7 \pm 14.1$ & $72.3 \pm 12.0$ & 0.052 \\
International normalized ratio & $1.03 \pm 0.08$ & $1.01 \pm 0.08$ & 0.545 \\
$\quad$ (mean \pm SD) & & & \\
\hline
\end{tabular}

Statistically significant at $P<0.05$

\section{Liver biopsy: Current referral practices}

To characterize the current liver biopsy referral practice at $\mathrm{KGH}$, all PLBs performed for chronic HCV from January 1, 1997, to December 31, 2007, were identified using the electronic database and paper records in the same manner as mentioned in the specimen acquisition section above. The technique used was recorded for each.

\section{Statistics}

The sample size was calculated to detect a mean difference of two CPTs between the two types of biopsy techniques. It was assumed, based on previous studies $(5,10)$, that the SD of the samples would be $3 \mathrm{CPTs}$. This resulted in an estimated sample size of $98($ alpha $=0.05$, beta $=0.10)$. The primary outcome was quality of the biopsy specimen as defined by the number of CPTs. Secondary outcomes included length, the number of PPTs, the estimated area of the biopsy, tissue fragmentation, number of central veins, diagnostic adequacy and total quality histopathological score. Continuous variables were analyzed using $t$ tests and nominal variables were analyzed using $\chi^{2}$ analysis with SPSS version 14 (SPSS Inc, USA).

The present study was approved by the Medical Research Ethics Board at Queen's University, Kingston, Ontario.

\section{RESULTS}

\section{Demographics}

The mean age of the patients who underwent US-guided biopsies was slightly greater than the patients who had non-USguided biopsies (46.3 years versus 42.5 years, repectively; $\mathrm{P}=0.018$ ); however, the two groups were similar in most other clinical characteristics (Table 1).

There was a difference between the two groups regarding the number of passes of the biopsy needle during the procedure. All 50 of the US-guided biopsies routinely required two passes of the needle, whereas only five non-US-guided biopsies needed more than one pass $(\mathrm{P}<0.001)$.

There were relatively equal numbers of complications between the two groups. Four patients in the US-guided and two patients in the non-US-guided group had postprocedure pain requiring analgesia before discharge. One patient who received a US-guided biopsy required a three-day admission to hospital as a result of a subcapsular hematoma but did not require blood transfusions or further interventions.

Primary and secondary outcomes

The US-guided biopsy specimens had significantly more CPTs (Table 2). The distribution of CPTs in each group did not show 
TABLE 2

Quality comparison of liver biopsies obtained by ultrasound- and nonultrasound-guided technique

\begin{tabular}{lccc}
\hline & $\begin{array}{c}\text { Ultrasound- } \\
\text { guided biopsy } \\
\text { (n=50) }\end{array}$ & $\begin{array}{c}\text { Nonultrasound- } \\
\text { guided biopsy } \\
(\mathbf{n}=50)\end{array}$ & $\mathbf{P}$ \\
\hline Primary outcome & & & \\
$\quad$ Complete portal tracts, $\mathrm{n}$ & $11.8 \pm 4.2$ & $7.4 \pm 4.5$ & $<0.001^{*}$ \\
Secondary outcomes & & & \\
$\quad$ Total length, mm & $24.4 \pm 5.1$ & $19.7 \pm 7.7$ & $0.001^{*}$ \\
Maximum width, mm & $0.75 \pm 0.14$ & $0.85 \pm 0.12$ & $<0.001^{*}$ \\
Area, mm ${ }^{*}$ & $12.27 \pm 2.8$ & $12.35 \pm 6.3$ & 0.933 \\
Partial portal tracts, $\mathrm{n}$ & $2.7 \pm 1.8$ & $3.7 \pm 2.0$ & $0.008^{*}$ \\
Total quality score & & & \\
5 & 1 & 4 & $0.026^{*}$ \\
6 & 0 & 5 & \\
7 & 11 & 10 & \\
8 & 38 & 31 & 0.200 \\
Able to grade and stage & 96 & 90 & \\
hepatitis C virus, \% & & & \\
\hline
\end{tabular}

Data presented as mean \pm SD unless specified otherwise. *Statistically significant

any significant outliers (Figure 2). The US-guided specimens were also longer $(24.4 \mathrm{~mm}$ versus $19.7 \mathrm{~mm} ; \mathrm{P}=0.001)$, had less fragmentation (Figure 3 ) and had a higher overall quality histopathological score $(\mathrm{P}=0.026)$. The non-US-guided biopsies had larger widths $(0.85 \mathrm{~cm}$ versus $0.75 \mathrm{~cm} ; \mathrm{P}<0.001)$ and more PPTs (3.7 versus $2.7 ; \mathrm{P}=0.08$ ) than $\mathrm{US}$-guided biopsies, but the two techniques were similar in the total area $\left(12.27 \mathrm{~cm}^{2}\right.$ US-guided versus $12.35 \mathrm{~cm}^{2}$ non-US-guided; $\mathrm{P}=0.933$ ) and overall ability to grade and stage the chronic HCV (96\% US-guided versus $90 \%$ non-US-guided; $\mathrm{P}=0.20$ ). There were no significant differences in the stage or grade of HCV between the two groups.

\section{Liver biopsy: Current referral practices}

Between January 1, 1997, and December 31, 2007, 763 PLBs for chronic $\mathrm{HCV}$ were performed at KGH. During this time, there was a pronounced trend moving away from non-US-guided to the US-guided technique. In 1997, 98\% of the biopsies were performed without US guidance, whereas in 2007 , $85 \%$ were completed by radiologists using the US-guided technique (Figure 4).

\section{DISCUSSION}

The results of the present study show that at our institution, US-guided PLBs obtained to grade and stage chronic HCV yielded specimens of higher quality than non-US-guided biopsies, based on the number of CPTs in the specimen. Also, we were able to show that over the past 10 years, there has been a trend toward more biopsies for HCV being performed by radiologists under US guidance, with no significant difference in complication rates within our study sample.

Recent literature has reported that liver biopsies containing fewer than 11 CPTs and less than $2 \mathrm{~cm}$ in length tend to underestimate the grade and stage of chronic HCV $(2,4)$. Our results show that, in our institution, US-guided biopsies routinely met these criteria while the non-US-guided biopsies did not. Although these biopsy quality recommendations have existed since 2003, it is unclear if these standards are universally met in

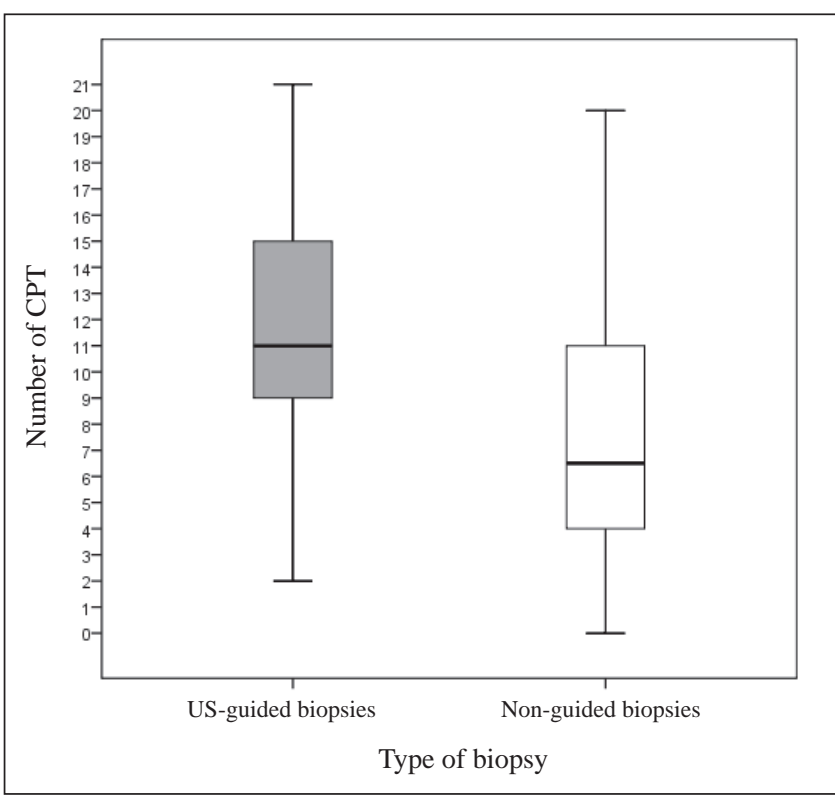

Figure 2) Distribution of number of complete portal tracts (CPTs) between the ultrasound (US)-guided and non-US-guided liver biopsy specimens

current practice. A meta-analysis that included more than 10,000 PLBs (5) showed mean values for length and width to be well below this accepted standard $(17.7 \pm 5.8 \mathrm{~mm}$ and $7.5 \pm 3.4 \mathrm{~mm}$, respectively). Additionally, in the trial conducted by Farrell et al (10) that compared US-guided with non-USguided techniques, specimen size and number of CPTs did not meet these criteria. Although our study was not randomized, we believe that it reflects routine practice. Although we did not find a difference in the ability to grade and stage HCV between the two techniques, the low number of CPTs in the specimens acquired by non-US-guided methods may lead to an underestimation of disease severity. Such underestimations could compromise treatment decisions $(17,18)$.

The trend toward liver biopsies for HCV shifting from gastroenterologists to the radiologists at our institution may be explained, at least in part, by the change in personnel requesting the test. Between 1998 and 2007, one of our hepatologists retired and a new hepatology graduate joined our department.

\section{Result of different needle types?}

One critique of our study is that different needles were used for the two groups, and that this could account for the difference in CPTs and length of specimen that was obtained. However, the literature is not clear on which type of needle actually produces the best specimens. There are two main types of biopsy needles currently in use. The Tru-Cut type uses a cutting technique while the Menghini or Jamshidi needles use a suction technique (19). In a systematic review (5) comparing more than 10,000 PLBs, Menghini needles were found to yield longer specimen lengths than Tru-Cut needles, but there was no difference in the number of CPTs per sample. Interestingly, the smaller gauge Menghini needles yielded longer lengths but contained fewer CPTs. However, Menghini needles produced more fragmented samples than specimens obtained with TruCut needles. 


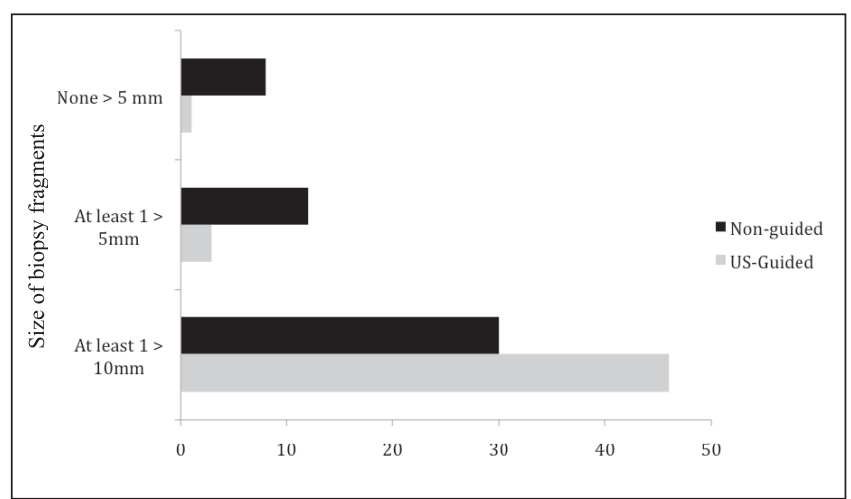

Figure 3) Degree of fragmentation of liver biopsies for chronic hepatitis C by ultrasound (US)-guided and non-US-guided techniques

In our study, the US-guided samples were obtained using an 18-gauge ASAP needle, which is an automated version of the Tru-Cut without the need for manual manipulation, while the non-US-guided specimens were obtained using a 16-gauge Jamshidi needle. Contrary to the results of the meta-analysis, we found that the ASAP needles produced longer specimens than the Jamshidi needles and had more CPTs per specimen, but the Jamshidi needles resulted in significantly more fragmentation.

Operator experience, the number of needle passes and complication rates

The experience of the physician performing the liver biopsy has been shown to influence the quality of the specimen and the rate of complications. Radiologists who had performed less than 15 US-guided biopsies obtained samples that were significantly shorter and contained fewer CPTs than those who had performed more than 150 biopsies independently (20). In Britain, gastroenterology registrars who had performed less than 20 PLBs had significantly higher complication rates than those who had completed more than 100 biopsies (21). In Switzerland, physicians who performed fewer than 20 biopsies also had higher complication rates than those who had completed 50 or more procedures (22).

In our study, the US-guided samples were obtained more than $80 \%$ of the time from one of three staff interventional radiologists, all of whom have performed more than 100 PLBs. The remaining samples were taken by senior radiology residents under direct supervision of the attending staff. With respect to the non-US-guided biopsies, the majority were performed by gastroenterology fellows under the supervision of an attending gastroenterologist. The number of PLBs performed by the fellows varied depending on their level of training, with most having completed 30 or more procedures by the end of their second year. There are no published reports that discuss PLB-quality differences between experienced and inexperienced gastroenterologists but we can assume, based on the radiology literature, that the difference in operator experience could contribute to the differences observed in the liver biopsy specimens in the present study.

All of the US-guided specimens required two passes of the biopsy needle to obtain a sample of tissue, whereas the majority of the non-US-guided biopsies needed only one. Although there is no literature that documents improvement in PLB

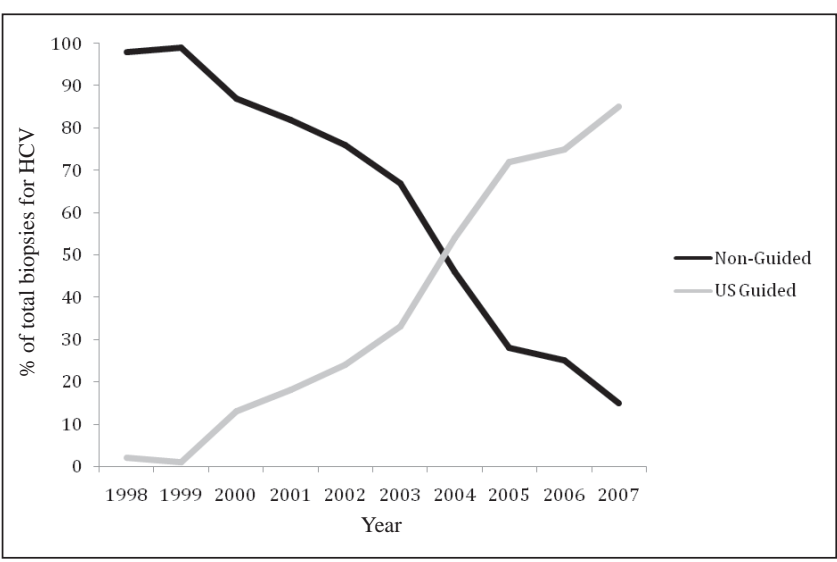

Figure 4) Ten-year review of percutaneous liver biopsies for chronic hepatitis $\mathrm{C}$ virus (HCV) at the Kingston General Hospital, Kingston, Ontario (1998-2007). US Ultrasound

specimen quality with more needle passes, it is reasonable to speculate that two passes would increase the chances of obtaining an adequate biopsy specimen. Of note, the study by Farrell et al (10) reported that significantly more needle passes were required in the non-US-guided group resulting in significantly more CPTs. There is extensive literature that documents an unfortunate increase in complication rates of PLBs with more passes of the biopsy needle into the liver (23-26) - most commonly hemorrhage, which makes this strategy somewhat less desirable. Although our study did not show a difference in complications between the groups, the study was not powered to do so.

The unsupported perception among gastroenterology trainees is that non-US-guided PLBs are associated with high complication rates and this may influence their desire to perform the procedure. Depending on the series, major complications related to outpatient PLB vary between $0.9 \%$ and $1.8 \%$ (27), and in the series by Myers et al (7), only $0.35 \%$ of patients experienced bleeding complications. This is relatively comparable with the admission rate for postpolypectomy bleeding $(0.2 \%)(28)$ - a procedure gastroenterology fellows perform on a routine basis.

\section{Amount of financial compensation?}

The amount of financial compensation received for performing the procedure may also influence physician referral patterns. Based on the Ontario Health Insurance Plan fee schedule, the compensation for a PLB is $\$ 70.80$, compared with elective esophagogastroduodenoscopy and colonoscopy to the terminal ileum at $\$ 102.75$ and $\$ 219.90$, respectively (29). At our institution, all attending gastroenterologists are on an alternate funding plan and, therefore, do not directly bill for procedures. However, because of shadow-billing and considering physicians on a fee-for-service schedule outside of Queen's University, some may be more likely to refer their liver biopsies to a radiologist so they can occupy their own procedural time with endoscopies.

\section{Should non-US-guided biopsies be abandoned?}

Despite the results of our study showing that US-guided biopsies at our centre produce higher quality liver biopsies, we believe that the non-US-guided technique remains a valuable skill to be learned by gastroenterology fellows. The wait list to obtain a 
US-guided biopsy in some jurisdictions can be long, potentially delaying the initiation of antiviral therapy. Until noninvasive tests to evaluate the degree of hepatic fibrosis are validated for diagnostic accuracy, liver biopsy will continue to be important for the management of HCV and other hepatic diseases.

Our goal now is to improve the quality of our non-US-guided biopsies performed for HCV. Based on our results, this could involve changing the type of needle used, the number of biopsy needle passes to retrieve a sample and obtaining a bedside US probe. Ultimately, once these changes are instituted, a prospective randomized study will need to be performed to compare the quality of the two techniques. We also encourage all centres performing liver biopsies for chronic HCV to review their current PLB practices to ensure that adequate samples are being obtained using the current criteria of 11 to 15 CPTs and greater than $2 \mathrm{~cm}$ in length per biopsy.

\section{REFERENCES}

1. Bravo AA, Sunil GS, Chopra S. Current concepts: Liver biopsy. N Eng J Med 2001;344:495-500.

2. Guido C, Guido M, Sonzogni A, Leandro G. Impact of liver biopsy size on histological evaluation of chronic viral hepatitis: The smaller the sample, the milder the disease. J Hepatol 2003;39:239-44.

3. Crawford AR, Lin XZ, Crawford JM. The normal adult human liver biopsy: A quantitative reference standard. Hepatology 1998;28:323-31.

4. Guido M, and Rugge M. Liver biopsy sampling in chronic viral hepatitis. Semin Liver Dis 2003;24:84-96.

5. Cholongitas E, Senzolo M, Standish R, et al. A systematic review of the quality of liver biopsy specimens. Am J Clin Pathol 2006; 125:710-21.

6. Cadranel JF, Rufat P, Degos F. Practices of liver biopsy in France: Results of a prospective nationwide survey. Hepatology 2000;32:477-81.

7. Myers RP, Fong A, Shaheen AA. Utilization rates, complications and costs of percutaneous liver biopsy: A population-based study including 4275 biopsies. Liver Int 2008;28:705-12.

8. Gilmore IT, Burroughs A, Murray-Lyon IM, et al. Indications, methods, and outcomes of percutaneous liver biopsy in England and Wales: Audit by the British Society of Gastroenterology and the Royal College of Physicians of London. Gut 1995;36:437-41.

9. Lindor KD, Bru C, Jorgensen RA, et al. The role of ultrasonography and automatic needle biopsy in outpatient percutaneous liver biopsy. Hepatology 1996;23:1079-83.

10. Farrell RJ, Smiddy PF, Pilkington RM, et al. Guided versus blind liver biopsy for chronic hepatitis C: Clinical benefits and costs. J Hepatol 1999;30:580-7.
11. Pasha T, Gabriel S, Therneau T, et al. Cost effectiveness of ultrasound-guided liver biopsy. Hepatology 1998;27:1220-6.

12. Younossi ZM, Teran JC, Ganiats TG, Carey WD. Ultrasoundguided liver biopsy for parenchymal liver disease. An economic analysis. Dig Dis Sci 1998;43:46-50.

13. Jacobs WH, Goldberg SB. Patient Care Committee of the American Gastroenterological Association. Statement on outpatient percutaneous liver biopsy. Dig Dis Sci 1989;34:322-3.

14. Abdalian R, Siadat F, Heathcote EJ, Guindi M. Adequacy of liver biopsies: Variability across different methods of specimen acquisition. Can J Gastroenterol 2008;22(Suppl A):168 (Abst).

15. Angtuaco TL, Lal SK, Banaad-Omiotek GD, et al. Current liver biopsy practices for suspected parenchymal liver diseases in the United States: The evolving role of radiologists. Am J Gastroenterol 2002;97:1468-71.

16. Batts KP, Ludwig J. Chronic hepatitis. An update on terminology and reporting. Am J Surg Pathol 1995;19:1409-17.

17. Yano M, Kumada $\mathrm{H}$, Kage $\mathrm{M}$, et al. The long-term pathological evaluation of chronic hepatitis C. Hepatology 1996;23:1334-40.

18. Poynard T, Bedossa P, Opolon P. The natural history of liver fibrosis progression in patients with chronic hepatitis C. Lancet 1997;349:825-32.

19. Grant A, Neuberger J. Guidelines for the use of liver biopsy in clinical practice. Gut 1999;45(Suppl 1):1-11.

20. Chevallier P, Ruitort F, Denys A, et al. Influence of operator experience on the performance of ultrasound-guided percutaneous liver biopsy. Eur Radiol 2004;14:2086-91.

21. Gilmore IT, Burroughs A, Murray-Lyon IM, et al. Indications, methods, and outcomes of percutaneous liver biopsy in England and Wales: An audit by the British Society of Gastroenterology and the Royal College of Physicians of London. Gut 1999;45(Suppl IV):1-11.

22. Froehlich F, Lamy O, Fried M, et al. Practice and complications of liver biopsy. Results of a nationwide survey in Switzerland. Dig Dis Sci 1993;38:1480-4.

23. Piccinino F, Sagnelli E, Pasquale G, et al. Complications following percutaneous liver biopsy. A multicentre retrospective study on 68,267 biopsies. J Hepatol 1986;2:165-173.

24. Wawrzynowicz-Syczewska M, Kruszewski T, Boron-Kaczmarska A. Complications of percutaneous liver biopsy. Rom J Gastroenterol 2002;2:105-7.

25. McGill DB, Rakela J, Zinsmeister AR, and Ott BJ. A 21-year experience with major hemorrhage after percutaneous liver biopsy. Gastroenterology 1990;5:1396-1400.

26. van der Poorten D, Kwok A, Lam T, et al. Twenty-year audit for percutaneous liver biopsy in a major Australian teaching hospital. Intern Med J 2006;36:692-9.

27. Garcia-Tsao G, Boyer J. Outpatient liver biopsy: How safe is it? Ann Inter Med 1993;118:150-3.

28. Gibbs DH, Opelka FG, Beck DE, et al. Postpolypectomy colonic hemorrhage. Dis Colon Rectum 1996;39:806-10.

29. Ontario Health Insurance Plan Schedule of Benefits and Fees. Digestive System Surgical Procedures. April, 2008. 


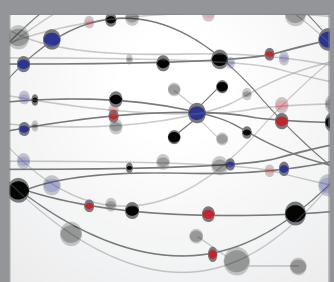

The Scientific World Journal
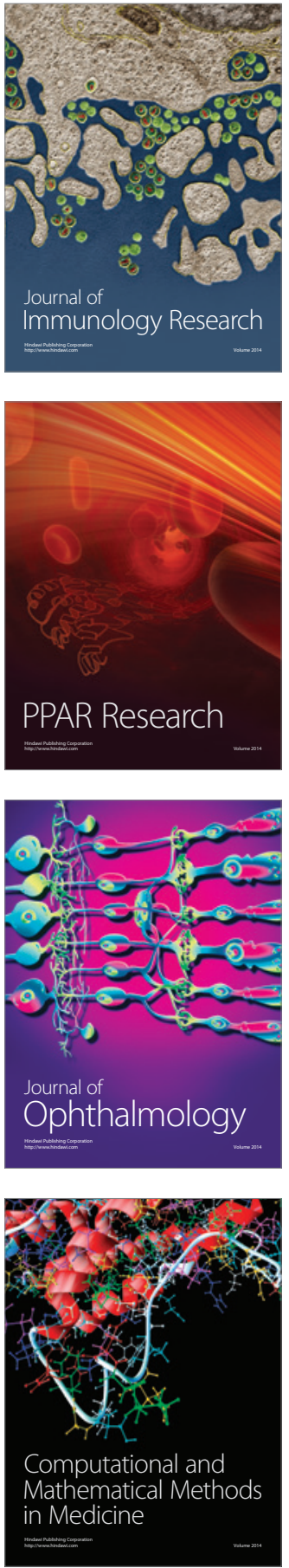

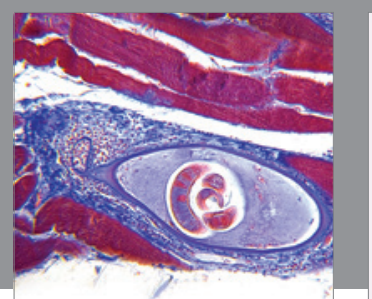

Gastroenterology Research and Practice

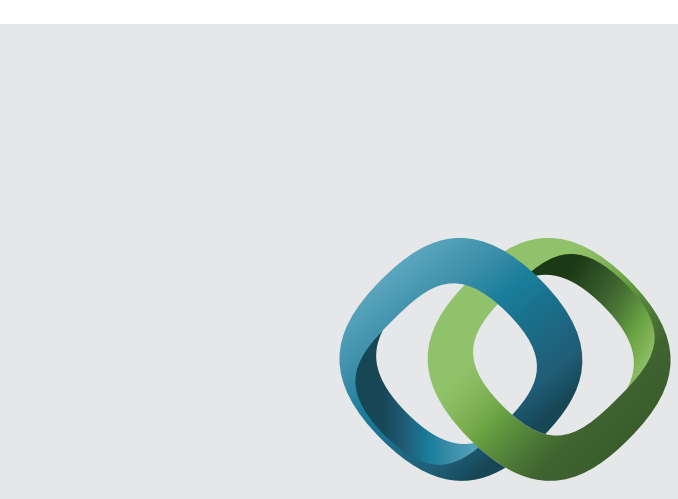

\section{Hindawi}

Submit your manuscripts at

http://www.hindawi.com
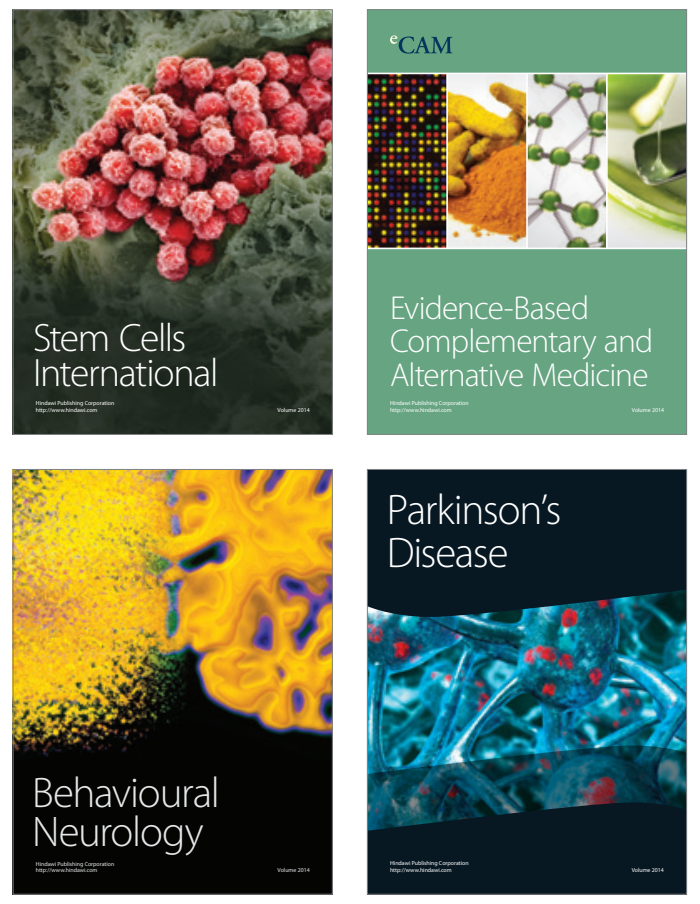
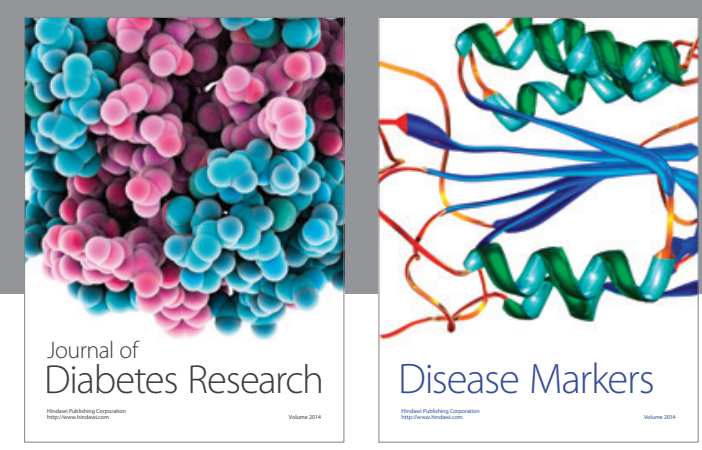

Disease Markers
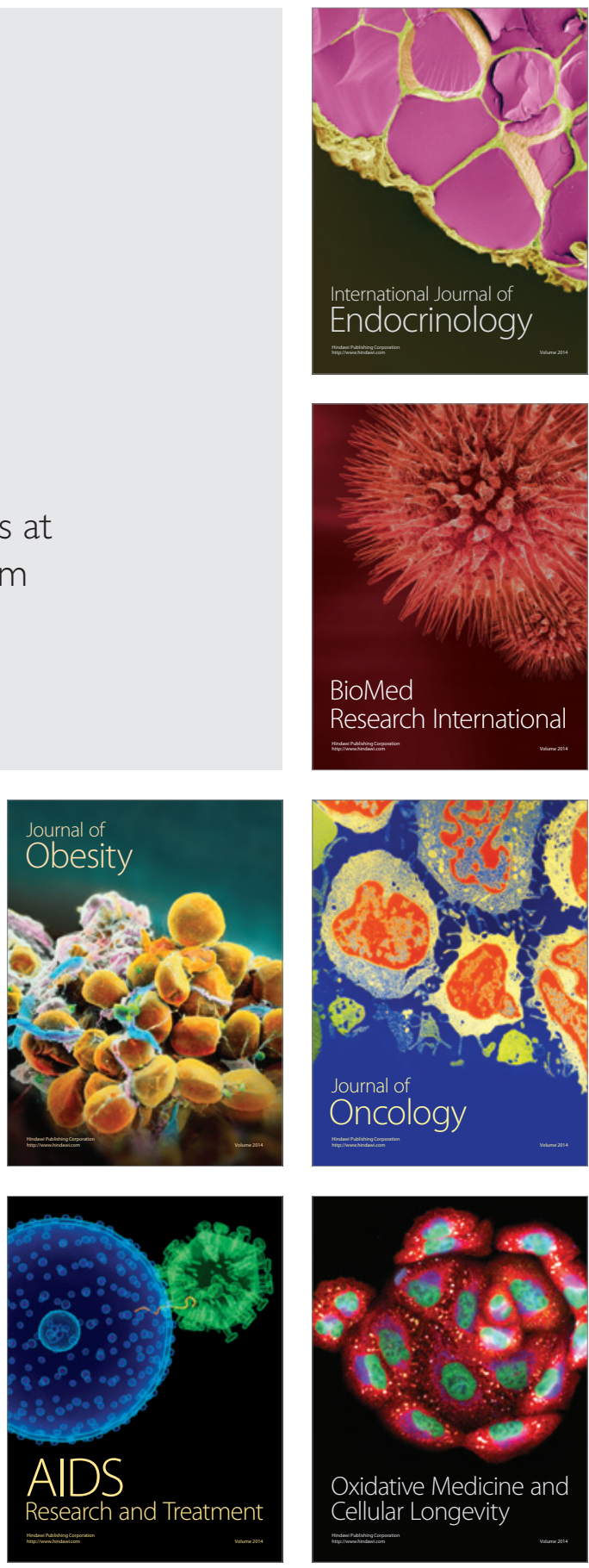